\title{
Results of Specific-Capacity Tests in Kings and Queens Counties, New York, 1919-82
}

By Anthony Chu

U.S. GEOLOGICAL SURVEY

Open-File Report 96-575

Prepared in cooperation with the NEW YORK CITY DEPARTMENT OF ENVIRONMENTAL PROTECTION 


\title{
U.S. DEPARTMENT OF THE INTERIOR BRUCE BABBITT, Secretary
}

\author{
U.S. GEOLOGICAL SURVEY \\ Gordon P. Eaton, Director
}

For additional information write to:

\section{U.S. Geological Survey}

2045 Route 112, Bldg. 4

Coram, NY 11727
Copies of this report may be purchased from:

U.S. Geological Survey

Branch of Information Services

Box 25286

Denver, CO 80225-0286 


\section{CONTENTS}

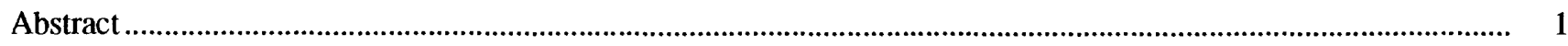

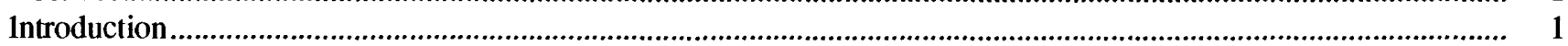

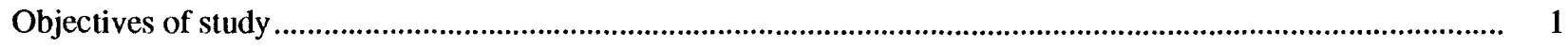

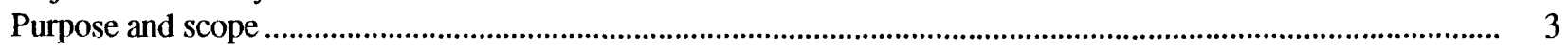

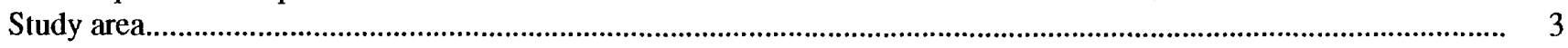

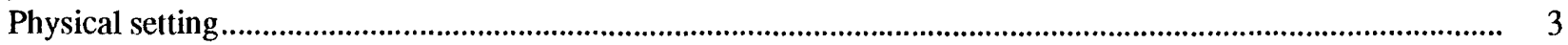

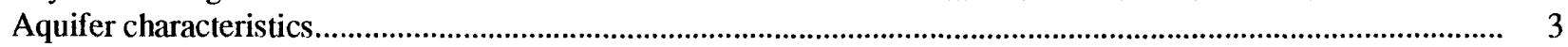

Upper glacial (water-table) aquifer................................................................................................... 3

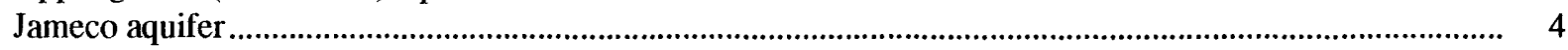

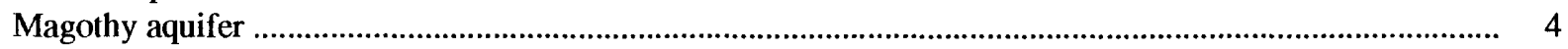

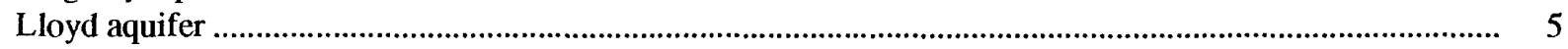

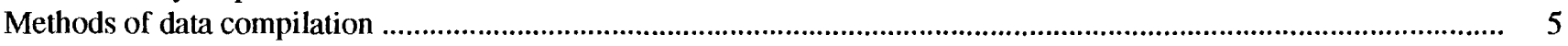

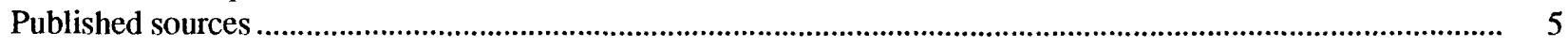

Criteria for selection of specific-capacity tests ............................................................................................... 5

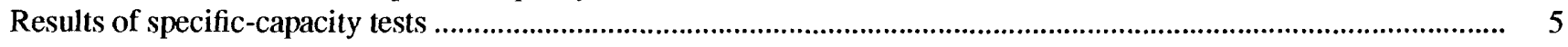

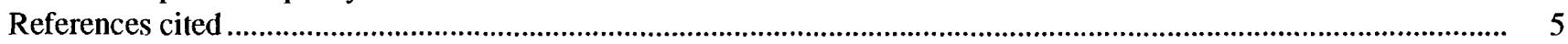

\section{FIGURES}

1. Map showing location and pertinent features of study area, Long Island,N.Y.

2. Generalized cross section showing relative positions of aquifers, Long Island, N.Y. ............................................

\section{TABLES}

1. Results of specific-capacity tests in Kings and Queens Counties, N.Y., 1919-82 
Multiply

inch (in.)

foot (ft)

square mile $\left(\mathrm{mi}^{2}\right)$

gallons per minute (gal/min) million gallons per day $(\mathrm{Mgal} / \mathrm{d})$ inch per year (in/yr)

feet per day $(\mathrm{ft} / \mathrm{d})$

square foot per day $\left(\mathrm{ft}^{2} / \mathrm{d}\right)$

gallons per minute per foot $[(\mathrm{gal} / \mathrm{min}) / \mathrm{ft}]$
By

To Obtain

Length

2.54

0.3048

centimeter

meter

Area

2.59

Flow

3.7854

0.04381

25.40

Hydraulic conductivity

0.3048

\section{Transmissivity}

0.0929

Specific capacity

0.2070 meters per day

square meter per day

liters per minute cubic meter per second millimeter per year

liters per second per meter

Sea level: In this report, "sea level" refers to the National Geodetic Vertical Datum of 1929 (NGVD of 1929) - a geodetic datum derived from a general adjustment of the first-order level nets of the United States and Canada, formerly called Sea Level Datum of 1929. 


\title{
Results of Specific-Capacity Tests in Kings and Queens Counties, New York, 1919-82
}

\author{
By ANTHONY CHU
}

\section{Abstract}

Results of specific-capacity tests from wells in Kings and Queens Counties were compiled for use in developing a ground-water flow model of western Long Island and are presented here. The specific-capacity data represent public-supply wells in Kings and Queens from 1919 through 1982 and are tabulated by county, well number, and date of test. These records include specificcapacity value, pumping rate, maximum drawdown, depth to water prior to pumping, and screened interval.

\section{INTRODUCTION}

Kings and Queens Counties, on western Long Island, N.Y. (fig. 1), obtain nearly all water (about $700 \mathrm{Mgal} / \mathrm{d}$; Buxton and Shernoff, 1995) from an upstate reservoir system operated by the City of New York. The possibility that this source will be inadequate during future droughts or other emergencies has prompted consideration of the underlying aquifer system in Kings and Queens Counties as a supplemental source. The aquifers beneath the two counties were pumped extensively through the mid-1940's, when overpumping caused significant drawdowns, and saltwater encroachment necessitated the shutdown of many wells in several areas. All public-supply pumping was stopped in Kings County (Brooklyn) in 1947 to prevent further saltwater encroachment, and several wells were shut down in western Queens County in 1974 for the same reason.

Pumpage for public and industrial water supply during 1904-47 averaged more than $120 \mathrm{Mgal} / \mathrm{d}$ (Buxton and others, 1981), and drawdowns in the aquifer system in Kings County in 1936 extended to as much as $35 \mathrm{ft}$ below sea level. Within 3 years after the cessation of pumping in Kings County in 1947, water levels in the water-table aquifer had recovered to within $8 \mathrm{ft}$ of predevelopment levels (Lusczynski, 1952) and have been near predevelopment levels since 1974. Even though a major cone of depression remained in eastern Queens County through the late 1980's, water levels there did not decline as far as they had in Kings County (Buxton and others, 1981). A major difficulty associated with the water-level recovery is that many of the structures and subways that were constructed when water levels were drawn down, particularly in central and east-central Kings County (fig. 1), are now flooded and require constant dewatering.

Because the aquifer system has largely recovered from the effects of early pumping, the question has arisen as to whether the system could safely be used as a supplemental water supply under a monitored pumping regime to augment the reservoir supply during water shortages. The major concerns are (1) the extent to which intermittent pumping would induce saltwater encroachment, and (2) whether the pumping would create sufficient flow gradients to induce the migration of contaminants (such as volatile organic compounds and nitrates) from surface sources to depths that provide potable water. The feasibility of using the Kings-Queens aquifer system for water supply will depend on hydraulic characteristics of the aquifers and the chemical quality of the pumped water.

In 1992, the U.S. Geological Survey (USGS), in cooperation with the New York City Department of Environmental Protection, began a 4-year study to develop a ground-water-flow model that can simulate a range of pumping scenarios and indicate what effects they would have on ground-water levels and flow patterns. The results would enable water managers to select optimum rates and locations for pumping to minimize saltwater encroachment and contaminant migration.

\section{Objectives of Study}

The principal goals of the study were to:

(1) Define the ground-water quality in the KingsQueens aquifer system, with emphasis on contami- 


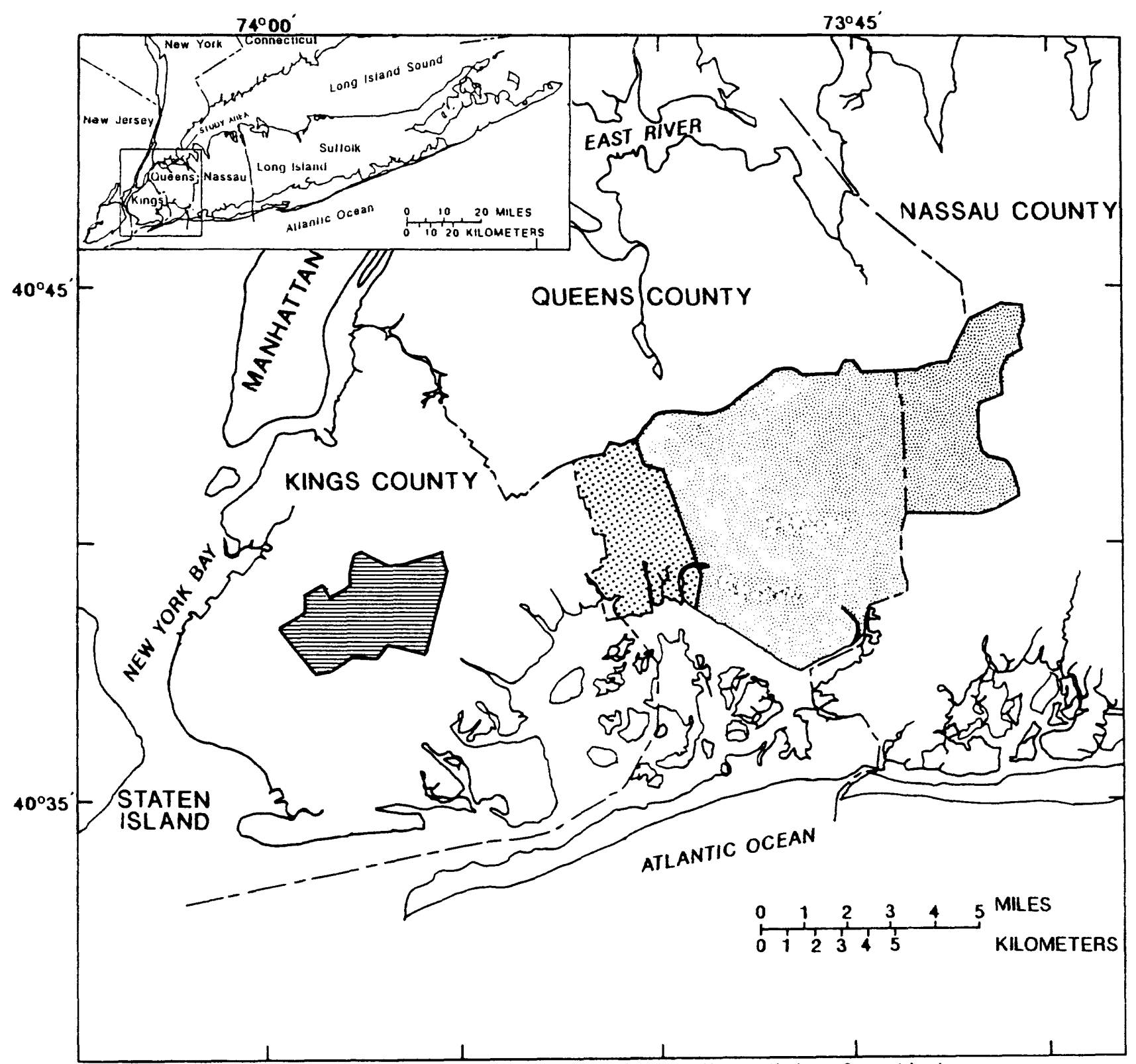

Base from U.S.G.S. 1:24000 series: Jamaica, Brooklyn. Central Park. Mount Vernon, Yonkers, Coney Island,

Flushing. The Narrows. and Far Rockaway.

\section{EXPLANATION}

Figure 1. Location and pertinent features of study area, Long Island, N.Y. (Modified from Chu and Stumm, 1995, fig. 2.) 
nation from volatile organic compounds (VOC's), bacteria, and saltwater.

(2) Establish a hydrologic data-collection network in Kings and Queens Counties to obtain data for use in model calibration and future monitoring of water levels and water quality.

(3) Develop a numerical ground-water-flow model to predict the effects of present and proposed watersupply pumping and dewatering operations on ground-water levels and flow patterns through numerical simulation.

The work entailed four phases:

(1) Reconnaissance of 106 wells that were sampled in Kings, Queens, and Nassau Counties in 1983 (Buxton and Shernoff, 1995). (Only 87 of these 106 wells were available for resampling; the others had either been destroyed, had clogged screens, or were inaccessible).

(2) Sampling the remaining wells for water quality to locate areas with high concentrations of contaminants.

(3) Installing 15 wells in three aquifers to provide hydrogeologic information, particularly on the location of the saltwater interface (Chu and Stumm, 1995), and to augment the water-level network.

(4) Creating a Geographic Information System (GIS) database for use in the development of the groundwater-flow model. The data files consist of well information that includes screen depth, aquifer, water levels, water chemistry, hydrogeologic framework of each aquifer and confining unit, pumpage, and specific capacity.

This investigation entailed collecting and compiling specific-capacity data from USGS records and from previous studies (Leggette \& Brashears, 1944; Roberts and Jaster, 1947).

\section{Purpose and Scope}

This report presents the specific-capacity data used to calculate hydraulic conductivities for the model. The data pertain to wells screened in the upper glacial, Jameco, Magothy, and Lloyd aquifers in Kings and Queens Counties. The report also briefly describes the physical and hydrogeologic characteristics of the study area and explains the methods used to select aquifer-test records. Results of specific-capacity tests in Kings and Queens during 1919-82 are given in table 1 (at end of report). The table is arranged by county, well number, and date.

\section{STUDY AREA}

The study area encompasses Kings and Queens Counties in the western part of Long Island and has a total area of about $189 \mathrm{mi}^{2}$ (fig. 1). This area is underlain by four major aquifers - the upper glacial, Magothy, Jameco, and Lloyd (fig. 2).

\section{Physical Setting}

The study area is bounded on the south by the Atlantic Ocean, on the east by Nassau County, and on the north and west by the East River and New York Bay (fig. 1); it includes bays, lagoons, islands, and barrier beaches along the southern shore. Precipitation, the sole source of naturally occurring freshwater on Long Island, ranges from 40 to $50 \mathrm{in} / \mathrm{yr}$ (Miller and Frederick, 1969). Altitudes range from $360 \mathrm{ft}$ above sea level on morainal deposits, to sea level at the coast. Many streams, and much of the low-lying swamp and marsh areas, were filled in as the area became urbanized.

\section{Aquifer Characteristics}

The principal aquifers in the study area are the upper glacial (water table), Jameco, Magothy, and Lloyd. This section briefly describes their geologic and hydraulic characteristics and cites the main references.

\section{Upper Glacial (Water-Table) Aquifer}

Pleistocene glaciation covered Long Island with a mantle of till, outwash, and glaciolacustrine deposits that form the upper glacial aquifer (fig. 2). Till, a poorly sorted mixture of clay, sand, gravel, and boulders, forms the moraines along northern Long Island and is poorly permeable. Outwash overlies the central and southern part of Long Island and consists of fine to coarse sands and gravels that are moderately to highly permeable. Glaciolacustrine deposits of clay, silt, sand, and gravel are found in central and eastern Long Island, and marine clay deposits are found along the southern shore of Long Island. These deposits are poorly permeable but contain thin local lenses of sand and gravel that are moderately permeable. 

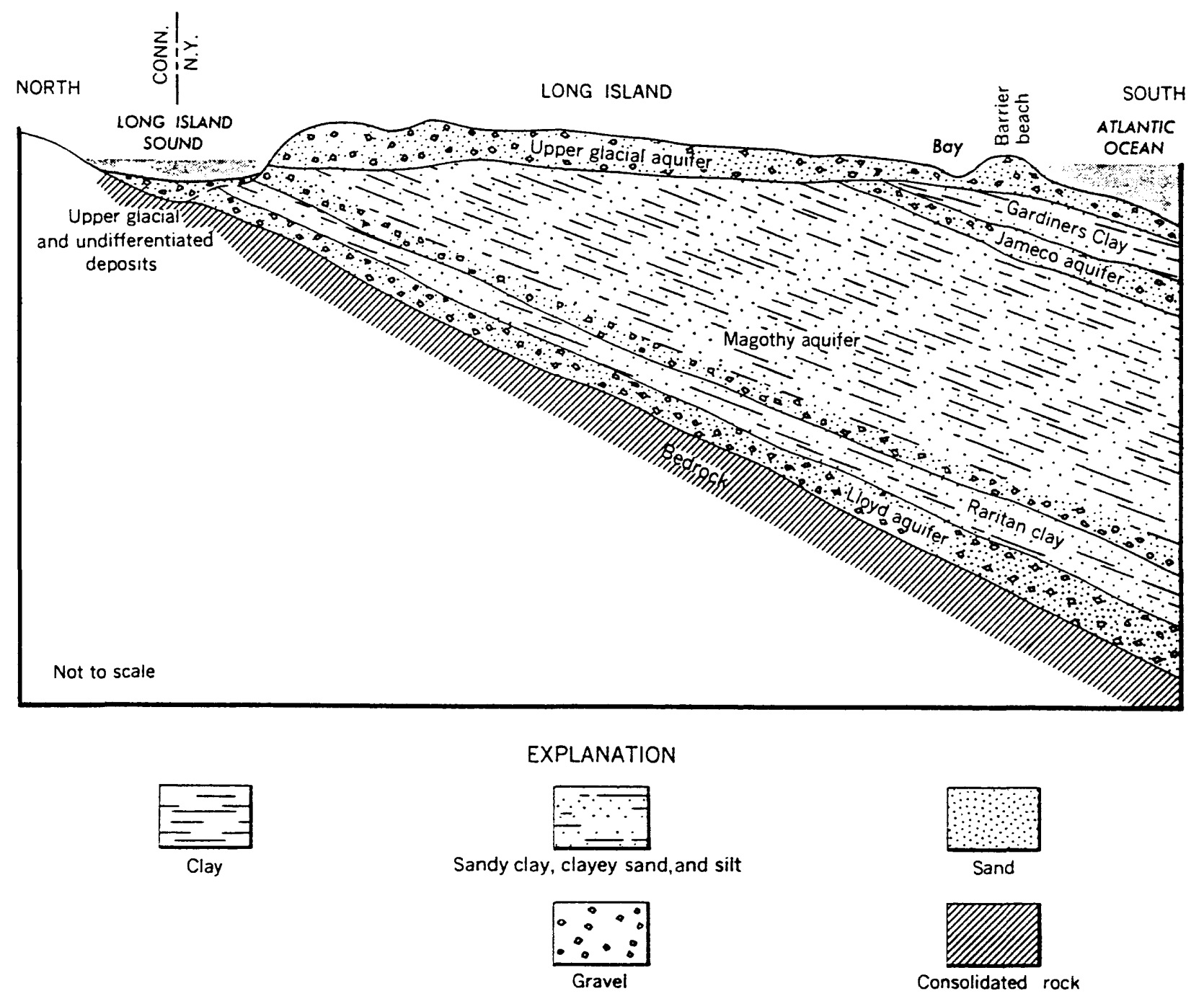

Consolidated rock

Figure 2. Generalized cross section showing relative positions of aquifers, Long Island, N.Y. (From Franke and McClymonds, 1972, fig. 8.)

The average horizontal hydraulic conductivity of the Pleistocene deposits ranges from $75 \mathrm{ft} / \mathrm{d}$ for till to $230 \mathrm{ft} / \mathrm{d}$ for outwash (Buxton and Modica, 1992). The average transmissivity is $24,100 \mathrm{ft}^{2} / \mathrm{d}$ in Kings County and 16,100 $\mathrm{ft}^{2} / \mathrm{d}$ in Queens County (McClymonds and Franke, 1972). The upper glacial aquifer is in hydraulic contact with the Magothy every where except along most of the southern shore, where the Gardiners Clay restricts vertical flow to underlying aquifers.

\section{Jameco Aquifer}

The Jameco aquifer, a southern-shore glacial stream deposit (fig. 2), lies unconformably beneath the
Gardiners Clay in Kings and Queens Counties. The Jameco aquifer consists of coarse to fine sand and gravel and is moderately to highly permeable. The average horizontal hydraulic conductivity has been estimated to be $267 \mathrm{ft} / \mathrm{d}$ (Soren, 1971). The average transmissivity is $16,100 \mathrm{ft}^{2} / \mathrm{d}$ in Kings County and $13,400 \mathrm{ft}^{2} / \mathrm{d}$ in Queens County (McClymonds and Franke, 1972).

\section{Magothy Aquifer}

The Magothy aquifer, of Cretaceous age extends throughout most of Long Island. It lies unconformably beneath the Pleistocene deposits, mostly the 
Jameco aquifer, in the southern half of the study area, but is absent throughout most of Kings County. The Magothy consists of alternating beds of clay, silt, sand, and gravel. The average horizontal hydraulic conductivity of the Magothy aquifer has been estimated to be $50 \mathrm{ft} / \mathrm{d}$ (Franke and Cohen, 1972). The average transmissivity of this aquifer, where present in Kings County is $11,400 \mathrm{ft}^{2} / \mathrm{d}$ and is $10,700 \mathrm{ft}^{2} / \mathrm{d}$ in Queens County (McClymonds and Franke, 1972). The Magothy is underlain unconformably by the Raritan confining unit (hereinafter called the Raritan clay), which restricts vertical flow.

\section{Lloyd Aquifer}

The Lloyd aquifer of the Late Cretaceous-aged Raritan Formation lies conformably beneath the Raritan clay and unconformably upon bedrock throughout most of Long Island. The Lloyd consists of fine to coarse sand and gravel and is poorly to moderately permeable. The average horizontal hydraulic conductivity has been estimated to be $40 \mathrm{ft} / \mathrm{d}$ (Franke and Cohen, 1972). The average transmissivity is 4,700 $\mathrm{ft}^{2} / \mathrm{d}$ in Kings County and $8,000 \mathrm{ft}^{2} / \mathrm{d}$ in Queens County (McClymonds and Franke, 1972).

\section{METHODS OF DATA COMPILATION}

Well-construction, test-duration, and pumpingrate criteria were set to standardize the specific-capacity data (table 1 ). Compilation procedures consisted of (1) review of previous studies, and (2) establishing criteria for selection of specific-capacity data.

\section{Published Sources}

Leggette and others $(1937,1938)$ compiled a record of wells in Kings and Queens Counties; specific-capacity tests were listed as part of the hydrogeologic data included in these bulletins. Updated compilations were published by Leggette and Brashears (1944), and Roberts and Jaster (1947) for Kings and Queens Counties, respectively.

\section{Criteria for Selection of Specific-Capacity Tests}

The historical specific-capacity-test results that were used in the development of the ground-water- flow model represent tests that met or exceeded minimum pumping-duration and yield criteria and wellconstruction requirements. Specific-capacity tests that ran 8 hours or more with a minimum discharge of $500 \mathrm{gal} / \mathrm{min}$ were considered an adequate stress on the aquifer. In addition, a minimum screened interval of $15 \mathrm{ft}$ and a minimum casing diameter of $8 \mathrm{in}$. were arbitrarily chosen as standards for tests selected for use in determining hydraulic conductivity values for the model. Where a specific-capacity test did not meet the set criteria, the deficient value is listed in the remarks column of table 1 .

\section{RESULTS OF SPECIFIC-CAPACITY TESTS}

Results of 162 specific-capacity tests conducted at 121 public-supply wells in Kings and Queens Counties for 1919-82 (table 1) include date of test, specific capacity, maximum pumping rate, depth to water (static and pumping), maximum drawdown, and screen elevation.

\section{REFERENCES CITED}

Buxton, H.T., and Shernoff, P.K., 1995, Ground-water resources of Kings and Queens Counties, New York: U.S. Geological Survey Open-File Report 92-76, $111 \mathrm{p}$.

Buxton, H.T., and Modica, Edward, 1992, Patterns and rates of ground-water flow on Long Island, New York: Ground Water, v. 30, no. 6, p. 857-866.

Buxton, H.T., Soren, Julian, Posner, Alex, and Shernoff, P.K., 1981, Reconnaissance of the ground-water resources of Kings and Queens Counties, New York: U.S. Geological Survey Open-File Report 81-1186, $64 \mathrm{p}$.

Chu, Anthony, and Stumm, Frederick, 1995, Delineation of the saltwater-freshwater interface at selected locations in Kings and Queens Counties, Long Island, New York, through use of borehole geophysical techniques, in Geology of Long Island and Metropolitan New York, April 22, 1995, Program with Abstracts: Stony Brook, N.Y., Long Island Geologists, p. 21-30.

Franke, O.L., and Cohen, Philip, 1972, Regional rates of ground-water movement on Long Island, New York, in Geological Survey Rescarch 1972: U.S. Geological Survey Professional Paper 800-C, p. C271-277. 
Franke, O.L., and McClymonds, N.E., 1972, Summary of the hydrologic situation on Long Island, N.Y., as a guide to water-management alternatives: U.S. Geological Survey Professional Paper 627-F, 59 p.

Lcggette, R.M., and Brashears, M.L., 1944, Record of wells in Kings County, New York, Supplement 1: New York State Water Power and Control Commission Bulletin GW-8, 135 p.

Leggette, R.M., and others, 1937, Record of wells in Kings County, N.Y.: New York State Water Power and Control Commission Bulletin GW-3, 175 p.

1938, Record of wells in Queens County, N.Y.: New York State Water Power and Control Commission Bulletin GW-6, 240 p.

Lusczynski, N.J., 1952, The recovery of ground-water levels in Brooklyn, New York, from 1947 to 1950: U.S. Geological Survey Circular 167, 29 p.
McClymonds, N.E., and Franke, O.L., 1972, Water-transmitting properties of aquifers on Long Island, N.Y.: U.S. Geological Survey Professional Paper 627-E, $24 \mathrm{p}$.

Miller, J.F., and Frederick, R.H., 1969, The precipitation regime of Long Island, N.Y.: U.S. Geological Survey Professional Paper 627-A, $21 \mathrm{p}$.

Roberts, C.M., and Jaster, M.C., 1947, Record of wells in Queens County, N.Y., Supplement 1: New York State Water Power Control Commission Bulletin GW-11, $123 \mathrm{p}$

Soren, Julian, 1971, Ground-water and geohydrologic conditions in Queens County, Long Island, N.Y.: U.S.. Geological Survey Water-Supply Paper 2001-A, 39 p. 


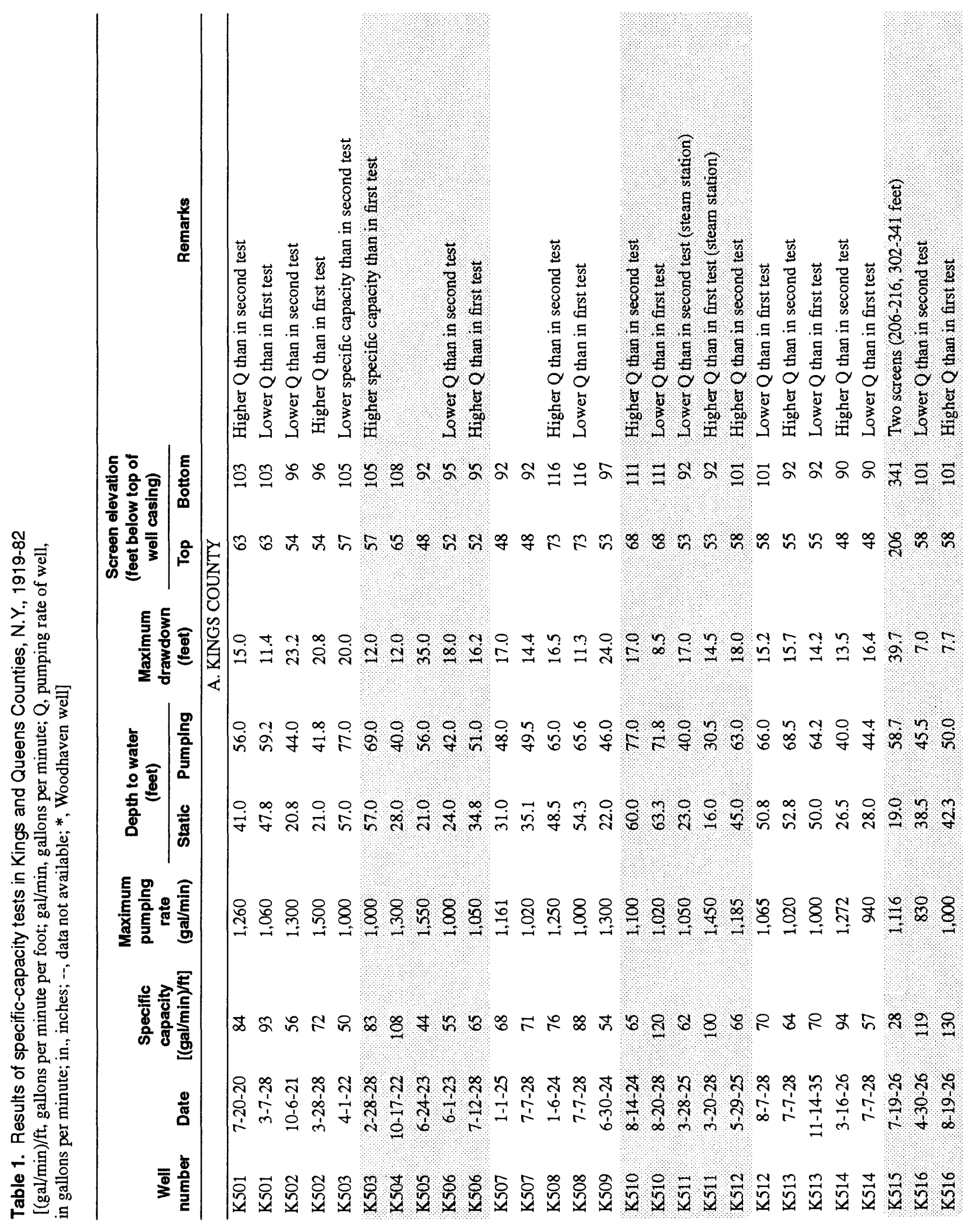




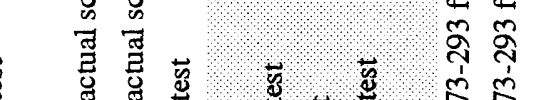

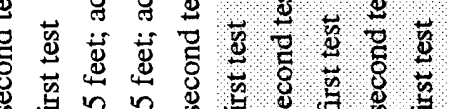

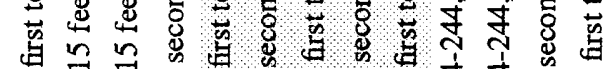

5 5.5 5.5 .5 .5 .5 5.5

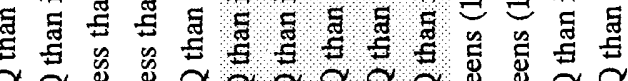

L

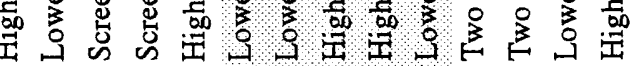

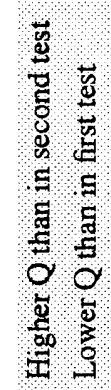

苾

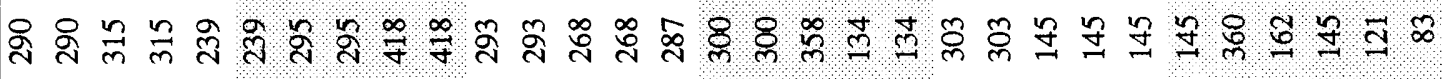

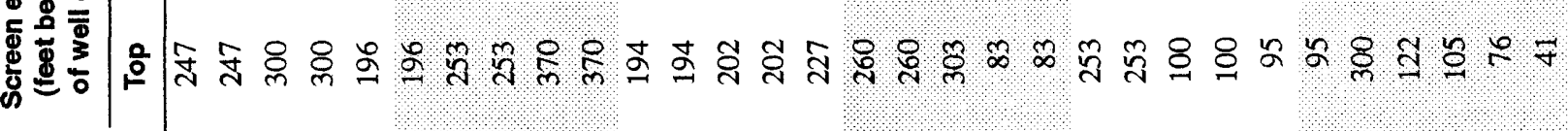

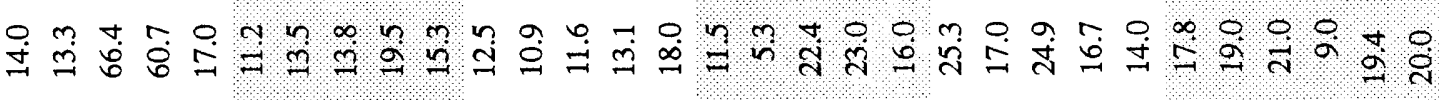

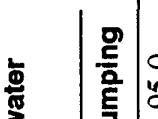

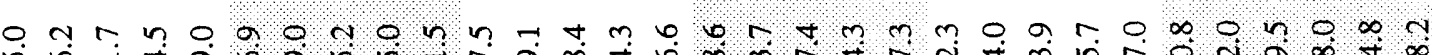

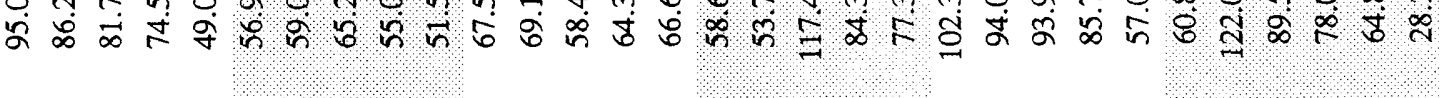

营

톨 을

\& \&

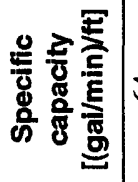

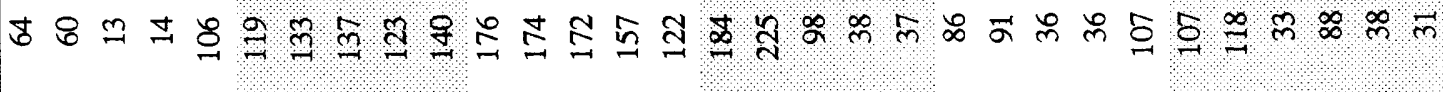

స 도 유 तี สิ

兽

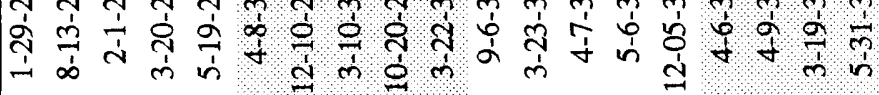

के के भै ?

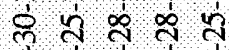
ते वे ले के

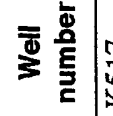

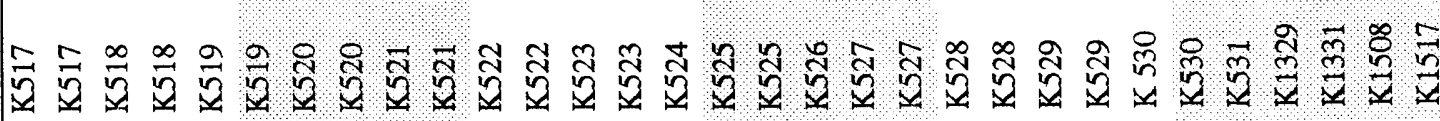




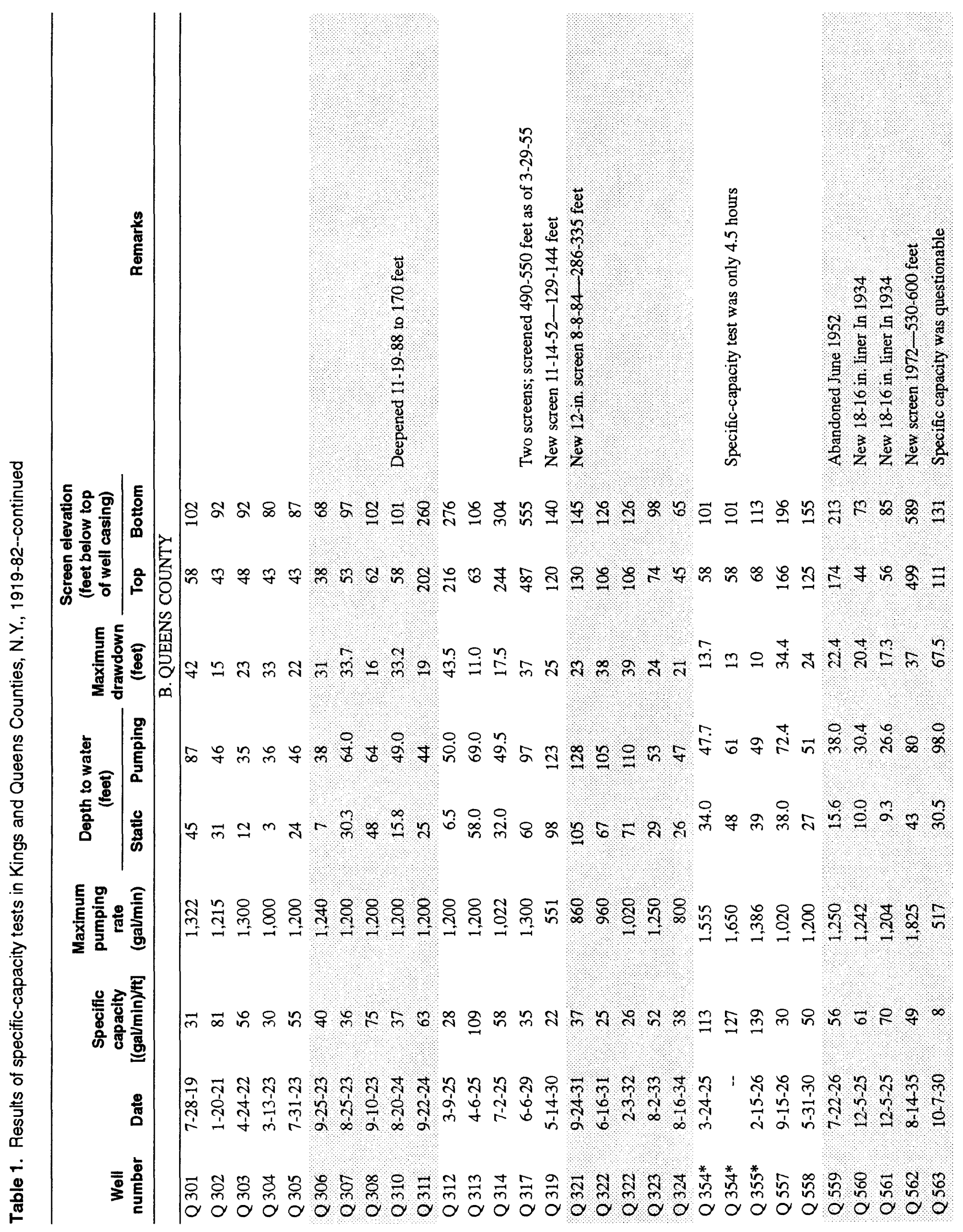




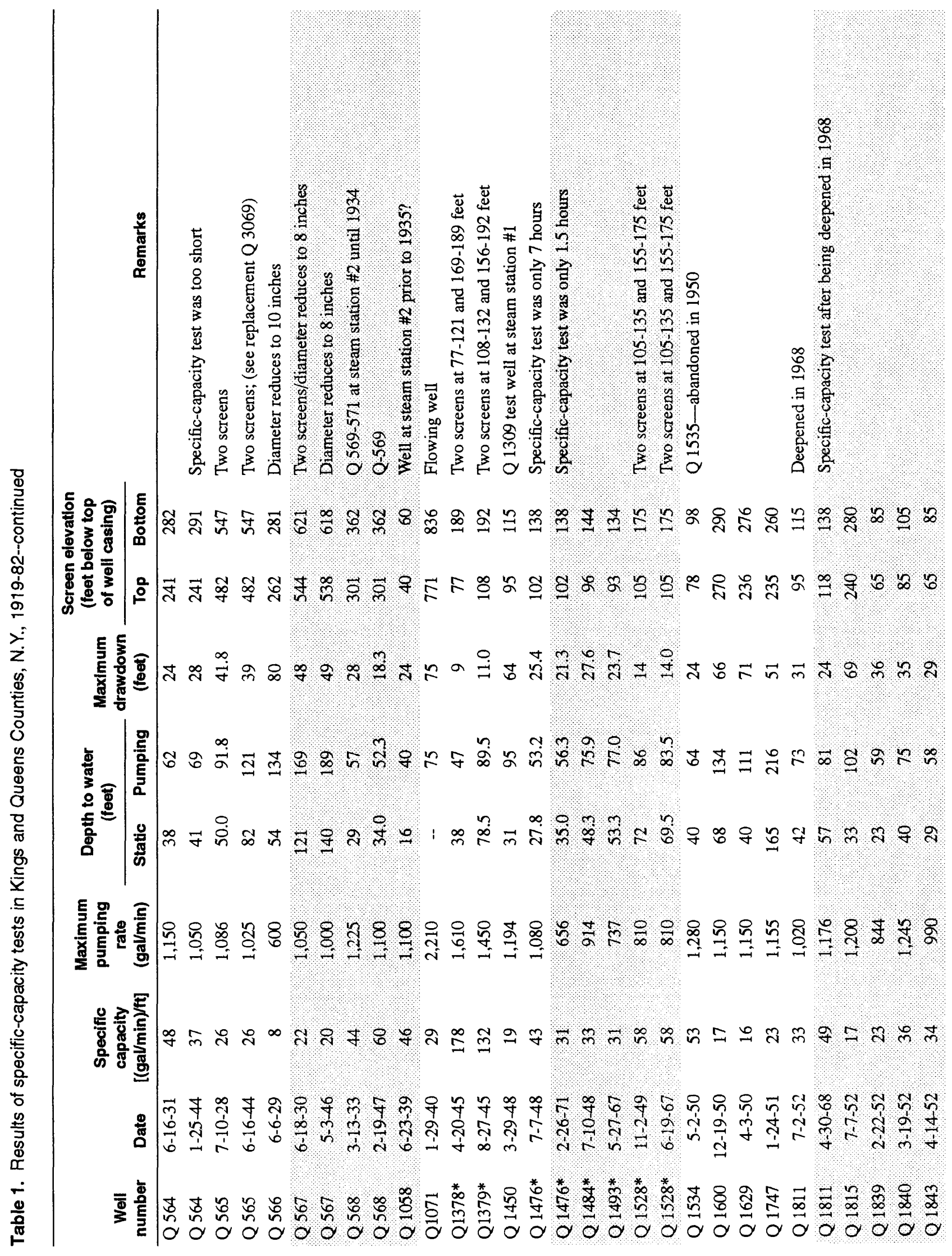




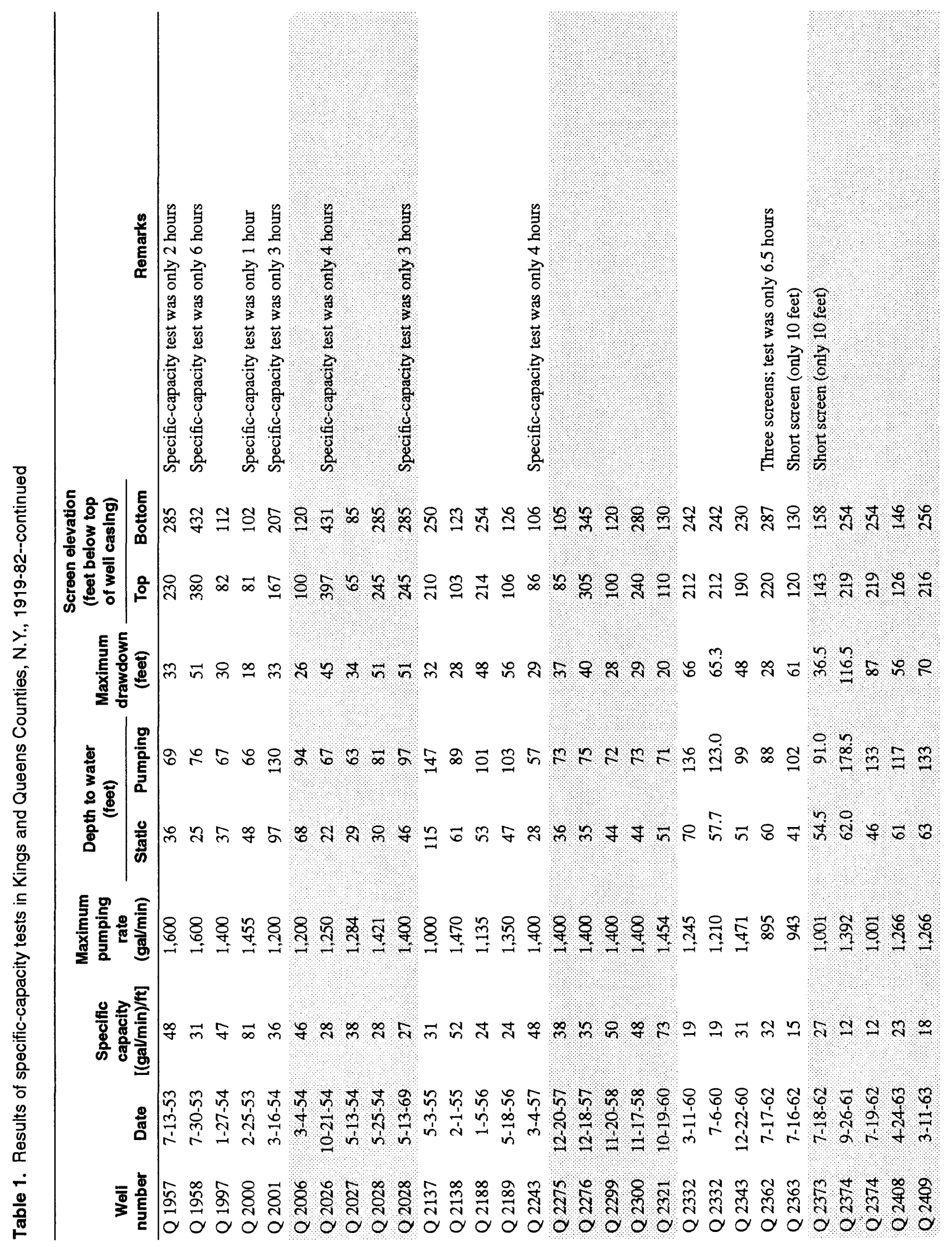




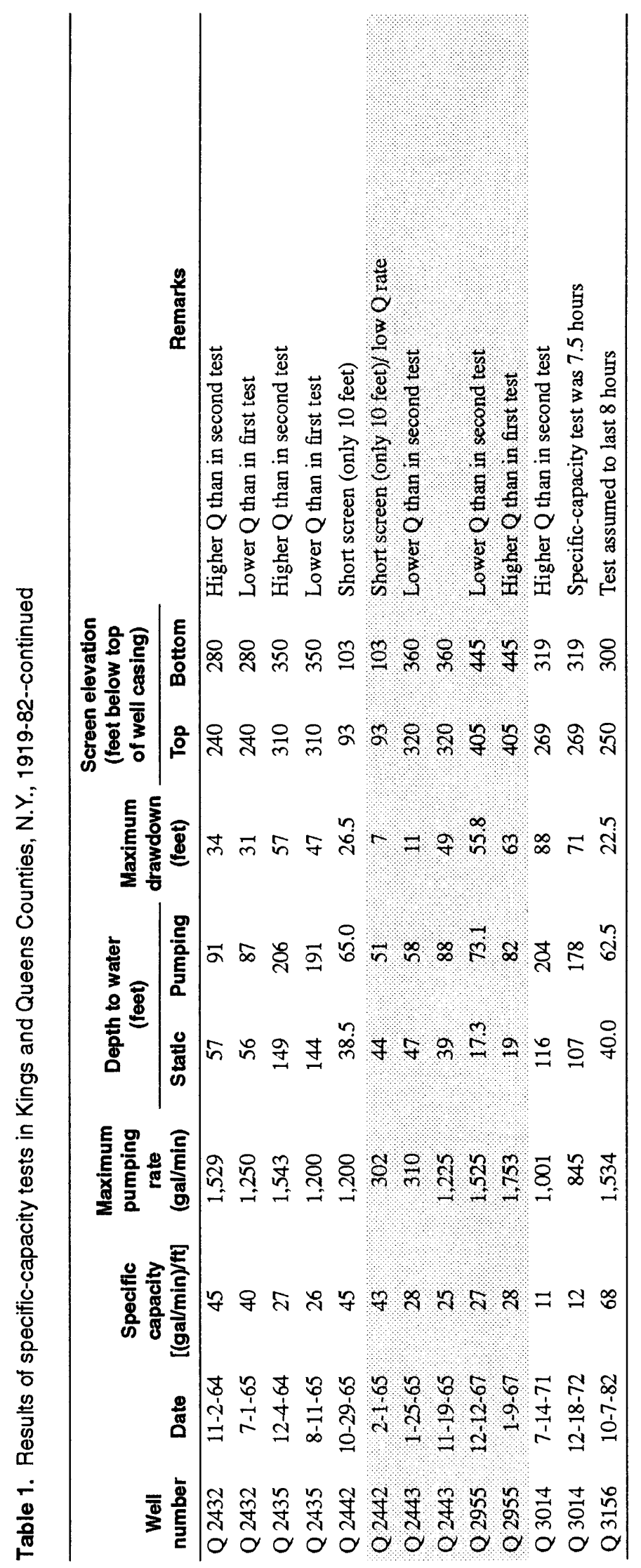

